次にその状態を保持し，撮影台に卧床した。

【結果】 立位条件の肩甲骨の傾斜は有意に卧位条件の肩甲骨の傾 斜より大きかった。

\section{座長集約 超音波(6～8)}

座長 医療法人社団山谷医院 三橋敏也 発表演題数53題中，超音波は 3 題とやや少ないように思われ た. 内容はいずれも超音波の最大の利点である無侵襲であること が謳われていた，演題 6，7は超音波検査のFirst choiseとしての 有効性, 演題 8 は検診時に内臟と並行して簡便に出来るとの発表 であった。

演題 6、高野の発表は副甲状腺における検出率をCT，Rlとの比 較をもとに検討した結果の報告である．結論はUS，CT，RIの三 法中超音波が検出率79\%と群を抜いており，その優位性は被曝， 費用の点からも明らかであるとしている。データも豊富かつ適切 で客観性があると思われた。

演題 7、大萱生の発表はIVPに対し腫場、結石等の検出率を比 較検討し，検出率では超音波がIVPより優れており，何より被曝 の点でははるかに優位であること、若年者に対しては無意昧な 被曝をさせるべきではないと言い切っている点は非常に興味深か つた。 又 6 及び 7 は同施設の報告であり，彼等の施設内に於け る(データをもとにした)被曝軽減に関する啓蒙の努力には敬意を 表する.

演題 8、宮川の発表は近年とかく危険度を言われている内脿壁

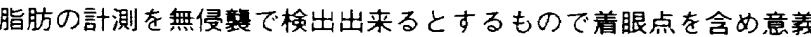
深い．CT等の検査でも不可能ではないが，無侵襲に加え患者の （費用を含めた）負担を考えた時、今後もっと実用の点で普及され ることを望む。

会場質疑で質問のあった如く超音波には常に手抜及び読影力に ついて熟練を要する点に問題がないとは言えないが，検查の中で 無侵䫓と言うこれに勝るものがないことから、X線発見100 年を 期にあらためて考えさせられた発表であった。

06 副甲状腺診断における超音波検亩の優位性について

（超音波，CT，RIによる検出率等の比較）

新日鐵室蘭総合病院放射線科

○高野正幹，大荁生 忠。細野明男

【目的】副甲状腺の画像診断には，超音波，CT，RIが広く行われ ているが，各法における副甲状腺の検出率等について検討した。

【対象及び方法】当院で1990〜1995年 5 月までに手術し病理診断 によって確認された二次性副甲状腺機能过進症 8 症例29腺(4740 42mg)について，三法の診断成績などについて検討した。読影は 超音波は検查担当技師，CT，Rlは専門医各 1 名が行った。

【結果】超音波で23腺 (79\%)，CTで15腺 (52\%)，RIで10腺(34 \%)検出された。検出された最小重量は超音波で $42 \mathrm{mg} ，$ CTで $168 \mathrm{mg}$ ，RIで $112 \mathrm{mg}$ ，検出されなかった最大重量は超音波で $356 \mathrm{mg}$ ，CTで1010mg，RIで1028mgであった。以上より超音波 検査が検出率，被曝の点から最も有効な検査であることが確認さ れた.

\section{7 臥画象診断における超音波検育の传位性について} 新日鐵室蘭総合病院放射線科

○大荁生 忠, 高野正幹, 細野明男

【目的】従来，腎の画像診断は経静脈性堅孟造影(以下IVP)が行 われてきたが、被曝量が多く問題があった。その点，筲超音波梌 查は被曝がなく、被検者の負担も少ない上経済的である。そこで 今回ＩVP と腎超音波検查を比較し，両者の検出率について検討 Lt.

【方法】平成 6 年のIVP及び腎超音波検査179例について腫瘍、 結石等の検出率を比較した。

【結果】IVPで腫煌 5 例、結石34例，腎超音波検査で腫瘍 8 例， 結石52例といずれも腎超音波検查の検出率が優れていた。また， 安全性，費用の面でも超音波検查が有利である。

今回の結果より，First choiceとして腎超音波検査を行い，その 結果より他の画像診断に進べきと思われた。

08 上腹部肥満評洒法としての超音波断層法による腹壁皮下䁕 眆厚測定の意義

松前町立松前病院 ○宮川照平

【目的】肥満人口が急速に增加している今日，肥満は健康対策 上重要な問題となってきている。上腹部肥満，また内落脂肪型 肥満は成人病にかかる可能性が高いという報告もある。そこで
今回，US検查と平行して，ウエスト測定とUS法による腹皮脂 厚の計測，そして肥満の合併症として知られる脂肪肝との発症 を基に、上腹部肥満及び内脐，皮下脂肪型肥満の判定を試みた ので報告する。

【方法と結果】対象は男子140名，女子123名である。腹部肥満 の指標としてウエストの測定は，BMI及び腹囲指数とほぼ同じ精 度を示し有効であると思われる。また腹皮脂厚には男女差がみら 九，男子は內㳟脂肪，女子は皮下脂肪型を示し、腹皮脂厚の測定 は內䑏型，皮下脂肪型を知る上で重要である。

\section{座長集約 画像工学(9～12)}

座長 函館中央病院 田中雄二

演題 9，10はRMI製156ファントムを使用したマンモグラフィ 一の基礎的な研究の2題である.

写真濃度を測定することにより最適なスクリーン、フィルム系を 選択するには重要な検討事項の1つである.

演題9はグリッドを使用することにより画像が改善され又散乱線 含有率も1/3に隇少したとの報告である。このことは乳房撮影ガイ ドラインにても指摘されている

マンモフィルムの処理については専用自現機の必要性が望まれて いるが現実的には難しい問題でもある.

演題10はフィルム賈度とシャーカステンの輝度の関係を述べてい るが筆者も、この輝度調節可能なシャーカステンに大きな興味を 持った．国内で未だ発売されていないとのことだが、入手出来れ ば他の分野でも役立つのではないかと思う。発表の中でフィル 厶濃度1.89で良い画像評価が得られたと報告しているが，このシ ヤーカステンの影整によるものだろうか? 又ガイドラインで言わ れている最適濃度よりかなり高值であるので，実際の臨床応用で の評価を聞きたい。

演題11はROC解析に連続確信度法を用いて、|・間接画像の評価 を行った。この方法は従来の評定法よりも簡単で精度も良いとの 報告である。これからも実験を進めてほりい。

演題12はエッジリンキング法を用いRI(甲状腺)画像の正しいエッ ジを求めている．この研究は北大の菊地もディスカッションの席 で述べていたが様々な分野に応用される基碟研究であると思う。

ミラー氏には今後とも多くの分野での追試をされ又学会に発表し ていただくことを望みます。

\section{RMI製156乳房ファントム像の画像解析}

東北大学医学部附属病院 ○佐久間俊光，佐々木清昭 NTT東北病院 大久敏弘，伊藤道明

【目的】RMI社よりACR規格の乳房ファントムが発売され，それ を用いた画像評価が一般的となっているが撮影システムの差を明 確に評価することは出来ない。そこでファントム像を定量的に解 析し，画像評価を行う上での問題点等について検討を行ったので 報告する。

【結果】1. massとfiberは，被写体コントラストが小さく形状の 違いが大きく反映し、散乱線で線コントラストが低下するた め、高コントラストのフィルムおよびグリッドの使用が効果的で ある。また粒状性の良いスクリーンノフィルムシステムを使用し てもフィルムコントラスが低いと良く描出されない. speckにつ いては，もともと被写体コントラストが大きいため散乱線の影翌 が受けにくく描出能にあまり变化は見られなかった。

10 RMI製156ファントムによる写真灌度とシャウカステン輝 度の検討

山形大学医学部附属病院放射線部

○鈴木隆二，岡田明男，鈴木 敏。佐藤昌見

江口陽一，加賀勇治

公立学校共済組合東北中央病院 高橋幸子

輝度調節型シャウカステン $\left(0 \sim 5000 \mathrm{~cd} / \mathrm{m}^{2}\right)$ を用い，RMI156型 ファントム画像評を 4 種類の素地濃度 $(0.92,1.23,1.73,2.37)$ で行った．濃度0.92は合格基準に達しなかったが，他の濃度は全 て合格した。中でも濃度1.78が最も高い得点であった。各瀆度で 使われたシャウカステン輝度は $(350 \sim 600 ， 650 \sim 950 ， 2000$ 台, 3000 台) $\mathrm{cd} / \mathrm{m}^{2}$ であったが，濃度2.37では輝度不足という意見 もあった．以上のことから，臨床における乳腺組織の写真濃度を 1.23〜1.78とし、これらを高輝度まで調節可能なシャウカステン で観察すれば、より多くの情報が得られると考える。 